\title{
Environmental Changes and Evolution of Settlement in the Limagne of Clermont-Ferrand (Massif Central, France)
}

\author{
Christèle Ballut, Frédéric Trement
}

\begin{abstract}
This paper presents a geomorphological work realised in an interdisciplinary CNRS programme called Zone Atelier. Its purpose is to analyse the relationships between the hydrological constraint in its complexity and the evolution of settlement between the First Iron Age and Early Middle Ages in the swamp of Limagne (French Massif Central). This paleoenvironmental research has combined the results of geomorphological and paleohydrological studies with the data on land use collected by archaeologists.
\end{abstract}

On the one hand, the geomorphological study has shown the evolution of humidity in space and time. The apparent homogeneity of the topography in the Limagne swamp, with a very even plain, actually disguises a mosaic of territories. Moreover, this humidity was linked to climatic variations, anthropogenic impacts and the possible subsidence of the plain. On the other hand, systematic fieldwalking conducted these last few years have revealed a density of population contradicting the idea of a marshland inhospitable to settlers in the protohistoric period and in Antiquity. The spatialisation of both geomorphological and archaeological data reveals the link between the evolution of the damp areas, forms and densities of settlement, and economic use of these territories.

Key words: palaeoenvironments, swamps, land occupation, Limagne, France

\section{Promjene okoliša i evolucija naseljavanja na području ravnice Limagne u blizini Clermont-Ferranda (Centralni francuski masiv)}

Ovaj je rad ostvaren unutar interdisciplinarnog programa zvanog Zone Atelier. Njegov je cilj analiza odnosa između složenih hidroloških obilježja istraživanog područja i razvoja naseljavanja od ranog željeznog doba do ranog srednjeg vijeka u močvari Limagne (Centralni francuski masiv). Ovo istraživanje paleo-okoliša se bazira na usporedbi geomorfoloških i paleohidroloških podataka s arheološkim podacima o korištenju zemljišta. Ova je geomorfološka studija pokazala promjene vlažnosti u vremenu i prostoru. Homogenost krajolika močvare Limagne je zapravo privid iza kojeg se krije jedan prostorni mozaik Što više, vlažnost je zapravo bila povezana s klimatskim promjenama, antropogenim utjecajima i mogućom subsidencijom tog prostora. S druge strane, sustavna terenska istraživanja $\mathrm{u}$ posljednjih nekoliko godina pokazala su iznimnu gustoću naseljenosti, što je nespojivo s idejom odbojne močvare za prethistorijsko i antičko stanovanje. Prostorni raspored geomorfoloških i arheoloških podataka otkriva vezu između evolucije vlažnih zona, oblika i gustoće naseljavanja, kao i ekonomsko korištenje tih područja.

Ključne riječi: paleo-okoliš, močvara, evolucija naseljavanja, Limagne, Francuska 


\section{INTRODUCTION}

This paper presents a work realised in a CNRS programme (National Scientific Research Center) called ZONE ATELIER. The aim of the programme is to assess the causes of environmental changes (anthropogenic, climatic and tectonic) and have a better understanding of the relationships between societies and their environment. It unites geomorphologists, archaeologists, palaeoecologists and also actual environmentalists.

In the Zone Atelier of the Loire watershed, a special interest is given to environmental palaeo-processes. Humid zones are the main field areas for several reasons. They are sensitive to environmental changes, they retain vestiges from the past (sediments, pollens), and they are attractive to populations, providing food (game, fish), water, raw materials. Sometimes their fertile soils, once drained, can be used for cattle-breeding or cultivation.

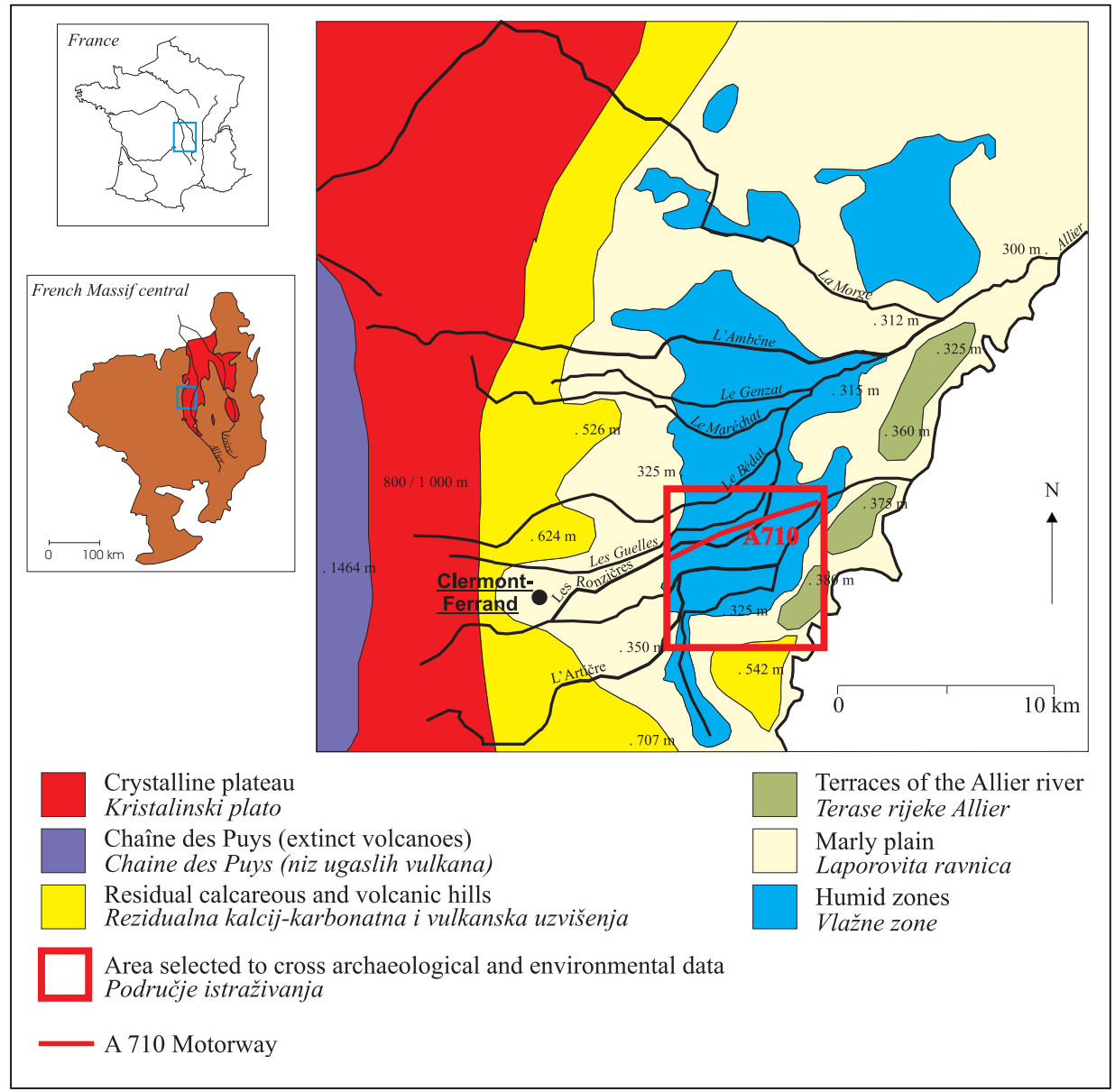

Fig. 1 The watershed on the left side of the Allier river

Sl. 1. Lijeva strana poriječja rijeke Allier 
The swamps of the Limagne of Clermont-Ferrand are situated on the downstream part of the watershed on the left side of the Allier river (fig. 1). In the west, these catchment areas extend on a crystalline plateau between 700 and 900 metres of elevation. In the east, they extend on the oligocene lands of marl and limestone (Limagne graben) between 300 and 450 metres. The rivers follow a steep slope $(20 \%)$ between the plateau and the plain. When they reach the plain, they have a torrential regime. However, downstream from their alluvial cones, the slopes become very gentle (inferior to $0,1 \%$ ) and damp areas occur. Apparently this humid zone is homogeneous : very flat, without relief, with dark soils mostly clayland everywhere (Derruau, 1949).

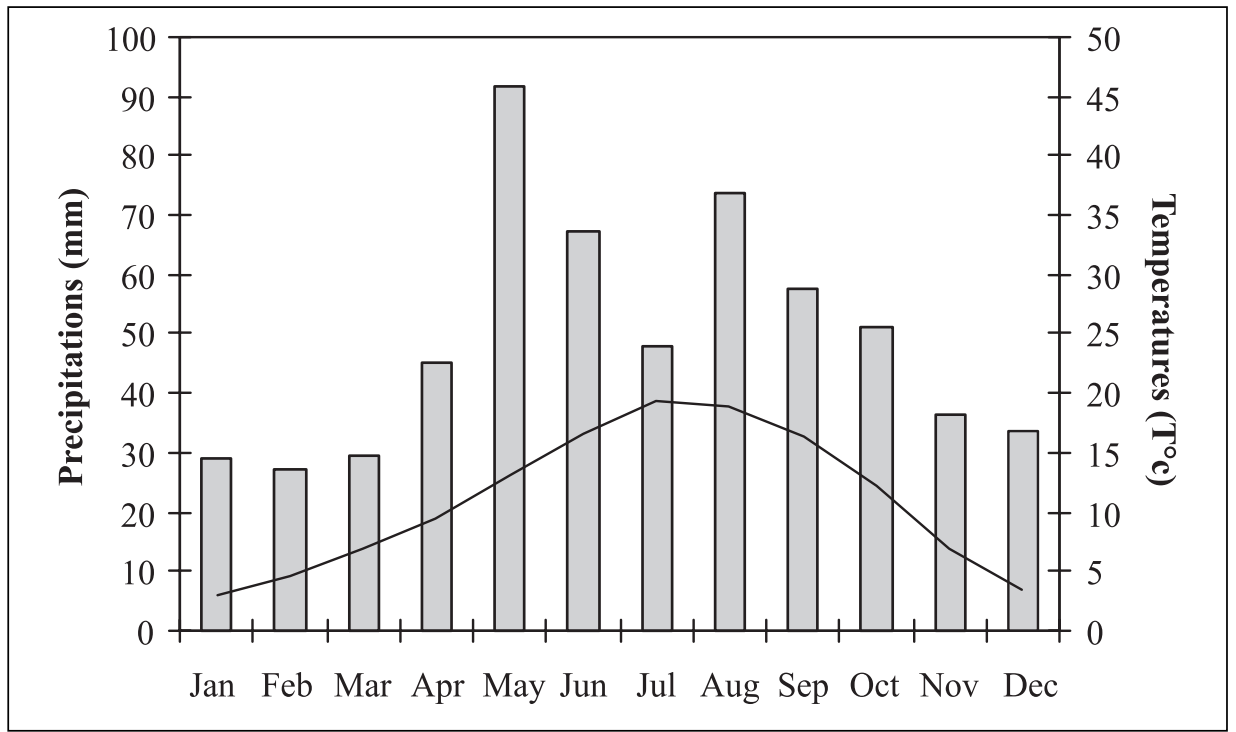

Fig. 2 A semi-continental climate

Sl. 2. Polu-kontinentska klima

At a regional scale, we know that the plain has been attractive for the last six thousand years. The Limagne has a sheltered climate (fig. 2) and fertile soils, in particular in the damp areas (Gachon, 1963). But the history of these areas is little-known. Waters are not in excess everywhere and we don't know exactly the reasons of the spatial and temporal variations. Our aim therefore is to identify the chronology and the spatial distribution of water in excess and to cross-examine the data on the environment and on land occupation to study the relationships between societies and their environment.

\section{APPROACH AND METHODS}

A spatial and diachronic approach is chosen to understand the evolution of environmental dynamics in the damp areas.

On the one hand, the dynamics are observed at the catchment area scale. We examine both colluviation on the hillslopes and alluviation in the valleys in order to study the flow 
of water and matter in the watershed. On the other hand, we work at the territory scale. We identify different physical units for a more precise study of the relationships between societies and environments. In 1997 we chose a test area of $8 \mathrm{sq} . \mathrm{km}$ located in the south of the humid plain to identify the territories (fig. 1). In this test area we observed a linear section from upstream to downstream along the A710 motorway. We also realised numerous bore holes with an earth auger. We made microtopographical, palaeotopographical and stratigraphic observations. We classically studied the palaeo-processes by geomorphological, palaeohydrological and pedological analysis (grain size analyses, mineralogy, calcium migrations in soils). In the same area, archaeologists realised systematic field walking. Unfortunately pollen analyses were impossible because of the bad preservation of the spores.

Both geomorphologists and archaeologists worked on the last six thousand years to observe long-term environmental changes to appreciate the sensitivity to change (in particular the speed of reaction of the environment), the diversity of environmental responses to the climatic variations, the anthropogenic actions and the tectonic movements, and also the relationships between land use and environmental changes. Most of the time, the chronological data were obtained by the numerous archaeological remains of the plain.

At the present time the results of the geomorphological study concerned the second part of the Holocene. Archaeological synthesis concerned the evolution of settlement from the Iron Age to the end of Antiquity (Trément, 2004). The programme continues to precise the environmental history between the Neolithic and the $\mathrm{XX}^{\text {th }}$ century.

\section{GEOMORPHOLOGICAL AND HYDROLOGICAL EVOLUTION OF THE CATCHMENT AREAS}

Three catchment areas located on the left bank of the Allier river were observed (Ronzières, Guelles, Morge rivers). In each one we observed the holocene deposits on the hillslopes, in the valleys and in the damp areas to precise geomorphological and hydrological palaeo-processes (Ballut, 2000).

Four main periods are identified from the Neolithic to the $\mathrm{XX}^{\text {th }}$ century.

- From the Neolithic to the middle of the second Iron Age (La Tene C2), we observe local increase of erosion on hillslopes due to rainwash in connection with human occupations. Most of the time, the morphogenesis is discreet, particularly at the beginning of the period. The hydrological evolution is influenced by climatic variations. The hydrological activity is moderate, except during the Sub-Boreal. From the late Neolithic to the late Bronze Age, overflowing is characterized on the alluvial cones and in damp areas.

- From the Iron Age to late Antiquity (c. 5th century AD), we observe a generalisation and an acceleration of erosion on all the slopes due to rainwash and rill wash (fig. 3) (Neboit, 1999). The hydrological activity is always moderate. Only a few catastrophic floods occur in every century (A710 data obtained along a linear section showing each hydrological main event). 
Christèle Ballut, Frédéric Trement - Environmental Changes and Evolution of Settlement in the Limagne of

Clermont-Ferrand (Massif Central, France)

S

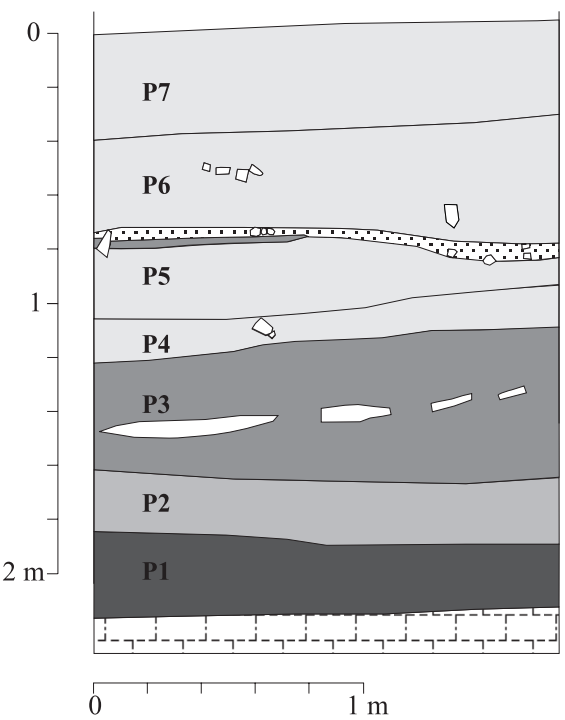

$\mathbf{N}$

$337 \mathrm{~m}$

La Tene D1

Hallstatt D3

Final Neolithic /

Ancient

Bronze Age

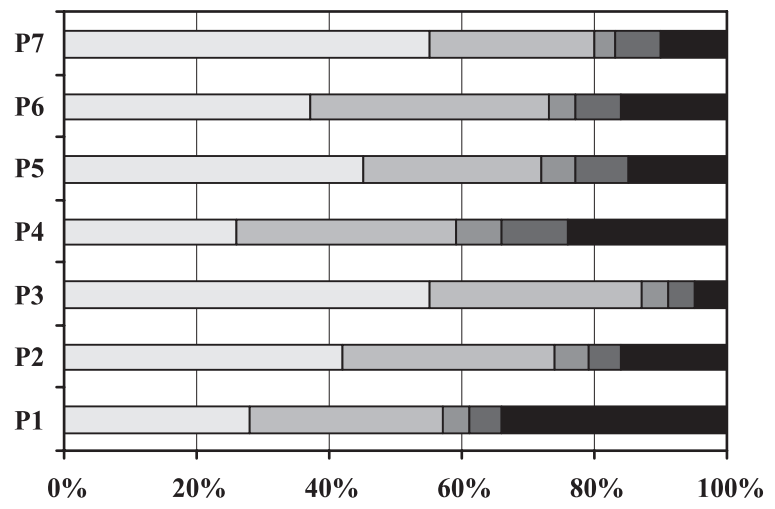

Brown and silty clay deposit a little sandy, columnar structure Smede muljevite glinene naslage, malo pjesdkovite, struktura u obliku stupića

Blocks in a silty clay deposit, columnar structure

Blokovi u muljevito-glinovitim naslagama struktura u obliku stupića

Black and clayey deposit,

compact structure

Crne glinene naslage,

kompaktna struktura

Grey and clayey deposit,compact structure,iron rust nodules (gley) Sive glinene naslage, kompaktna struktura s željezno-hrđavim nodulima

Black and sandy loam deposit, compact structure

Crne pjeskovito glinovite naslage, kompaktna struktura

White/grey and silty clay deposit, calcareous and marly alteration Bijelo/sive muljevito glinovite naslage, kalcij-karbonatne i laporovite u izmjeni

Small sandy deposit (rill wash) Manje pjeskovite naslage

Marly blocks / Laporoviti blokovi

P1 to P7 : samples / P1 do P7: uzorci

$\square$ Clay $\square$ Fina $\quad \begin{aligned} & \text { Fine sil } \\ & \text { Fini mulj }\end{aligned}$
$\square \begin{aligned} & \text { Fine-grained sand } \\ & \text { Sitnozrni pijesak }\end{aligned}$
$\begin{aligned} & \text { Coarse-grained sand } \\ & \text { Grubi pijesak }\end{aligned}$

Fig. 3 Section between a marly slope and a damp area in the Morge watershed

Sl. 3. Profil područja između laporovite padine $i$ vlažne zone porječja Morge

- From late Antiquity to the $\mathrm{XX}^{\text {th }}$ century (1960s), erosion is still generalisated and accelerated on all slopes in relation with rainwash and rill wash. At the same time overflowing of rivers increases. It is linked to a modification of the ratio between water supply and sediment yield due to the arrival of the eroded matter in the river beds (Bravard, Petit, 1997). This new hydrodynamic continues until the $X^{X^{\text {th }}}$ century with variation of intensity. The hydrological events are more important and frequent at the beginning of the Middle Ages and during the Modern Period. 
Starting from the 1960s, erosion still exists on the slopes due to rainwash and rill wash, even if some slopes are abandoned by agriculture. In the plain, humidity is not as important as before owing to the improvement of an efficient drainage scheme in the damp areas and to the construction of retention basins in the watershed.

On the left bank of the Allier river, the studied catchment areas have provided evidence of an acceleration and generalisation of erosion on all slopes in the plain as early as the late age of La Tene, as a consequence of a more intensive agricultural exploitation (Trément, 2002). Records of such morphogenesis (again enhanced by brooks) became apparent in the alluvial deposits only in the late Antiquity. Five thousand years later, the eroded matter comes to river bed. We don't know exactly why it took a so long time to have a hydrological response to the accelerated erosion on the hillslopes. Three reasons are possible. The period is often described by palaeo-environmentalists as having heavier rainfall (Magny, 1995). The archaeological context is not well known and we could also imagine the worst maintenance of landscapes in Limagne at the end of the Antiquity. Finally, the crossing of a threshold of resistance to erosion in the watershed is probable as well.

\section{GEOMORPHOLOGICAL AND HYDROLOGICAL EVOLUTION OF THE DAMP AREAS}

The dynamics of the watershed explains a part of environmental changes in the humid plain. The study of the sedimentation in the dampness areas helps us to determinate the variations of humidity in space and in time as well. Most of the collected data was found along the A710 cross-section from upstream to downstream the humid zone.

This cross-section shows a regularised topography (fig. 4). We observe depressions corresponding to the drainage axes in the marly plain (centre of würmian basins) separated by higher parts. Today it is impossible to see these two different zones because the depressions are filled in by alluvial and colluvial deposits. On the higher parts of the marly plain, the soils are brown-dark, formed with clay and loam, and present a polyhedral structure. Usually, the ground water doesn't reach the surface, even if the soil permeability is low. In the depressions four different sorts of dampness manifestations are observed. Near the hills of the plain, the soils are brown, clayey and loamy, with a polyhedral structure. The colluviation filled in the depression, especially until the Iron Age, and today they are deeply saturated in water $(30-50 \mathrm{~cm})$. In the middle of the humid plain we could see dark and clayey soils. In the east part, they have a vertic structure corresponding to seasonal rise of the ground water. In the west part, we also observed rivers overflowing with flooding and alluvial deposition especially since the late Antiquity. Finally, other areas show a marked stagnation of water that could be in excess all years long. The A710 cross-section shows that the situation of these last areas is linked to a horst parallel to the Allier river and perpendicular to its tributaries. This horst obstructs water behind smaller hills. From the Late Glacial to the actual period, the tectonic movement is nearly 1,50 metres (Ballut, 2000).

Consequlently water in excess could be explained by:

- rainwash from the higher to the lower parts of the marshes,

- seasonal rise of the ground water, 
Christèle Ballut, Frédéric Trement - Environmental Changes and Evolution of Settlement in the Limagne of Clermont-Ferrand (Massif Central, France)
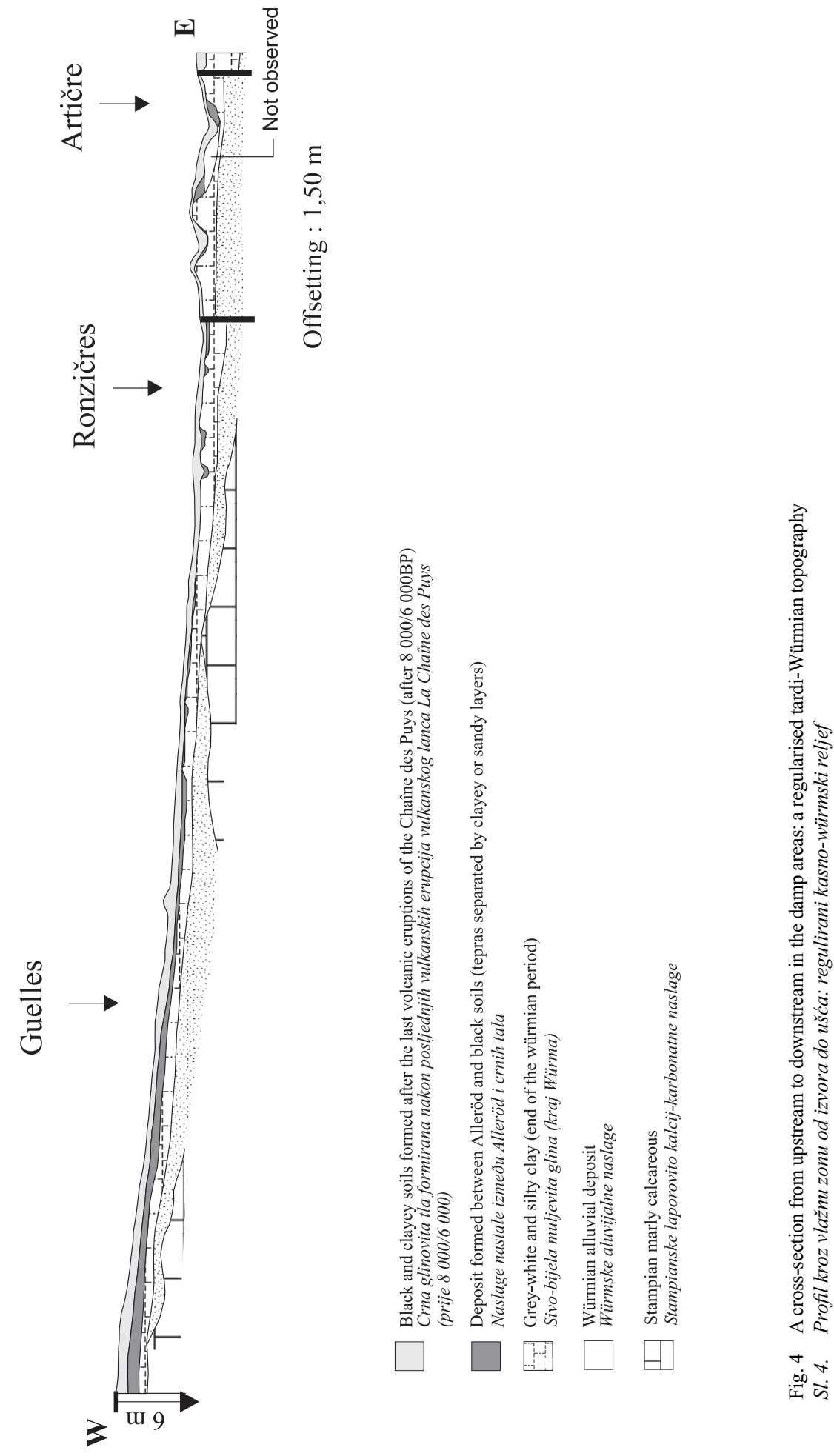
- rivers overflowing with flooding and alluvial deposition in the lower parts of the plain, - alluvial blocking of tectonic origin.

Palaeotopography and tectonic activity explain the spatial variations of dampness in the humid plain. By the time, the geomorphological data obtained in the watershed and the pedological data obtained in the damp area lead us to associate dampness manifestations to physical unites. The precise mapping of these data gives an opportunity to understand land use and human occupation that could be explain both by political and environmental evolution.

\section{THE RELATION SHIPS BETWEEN SOCIETIES AND DAMP AREA FROM THE IRON AGE TO THE MIDDLE AGES IN THE LIMAGNE OF CLERMONT-FERRAND}

Even though the authors are aware that there is no simple correlation between land occupation and the processes of sedimentation, the confrontation of results separately obtained by each discipline allows them to identify three major phases characterised by socio-economic systems and environmental processes that are specific and obviously interrelated : - the first covers a greater part of the Iron Age ; - the second extends from the end of the Iron Age to the late Antiquity ; - the third begins in late the Antiquity and extends into the end of the Middle Ages.

From the final Bronze Age to La Tene C2 (fig. 5).

Until the beginning of La Tene, dampness varied according to the seasonal fluctuations of the ground water. The colonisation of the damp plain resulted in a general densification of settlements on all kinds of environments (top of hills, slopes, alluvial terraces) in a context of demographic growth. Archaeo-zoological work has suggested that many territories must have been kept as pasture in order to feed numerous animals (mostly cattle, sheep and pigs) (Jones, in Guichard, 2000).

From the end of La Tene to the High Empire (III-IVth centuries) (fig. 6).

From the 2nd century BC great drainage schemes ensured a methodical use of the more fertile soils in the plain. These great schemes can be related to the evolution of agricultural techniques but also to the increased centralisation of the Arverne territory in a context of continuous economic and demographic growth. During the High Empire the development of Augustonemetum, the new Arverne capital, was accompanied by a systematic enhancement of the Clermont-Ferrand basin. The landscape was then largely dominated by agriculture.

From the late Antiquity to the Early Middle Ages (fig. 7).

From the end of the Antiquity through the Early Middle Ages, the studied area knew deep changes. The drainage system dating back to the Antiquity was apparently no longer efficient or was even abandoned. Almost half the area was subjected to hydrological constraints. Rural settlements were drastically reduced, but remained essentially in the plain, even in the more exposed areas. The damp environment revealed itself as fully attractive in the context of a little-known rural economy, in which the exploitation of marshland probably played the major role. 
Christèle Ballut, Frédéric Trement - Environmental Changes and Evolution of Settlement in the Limagne of Clermont-Ferrand (Massif Central, France)

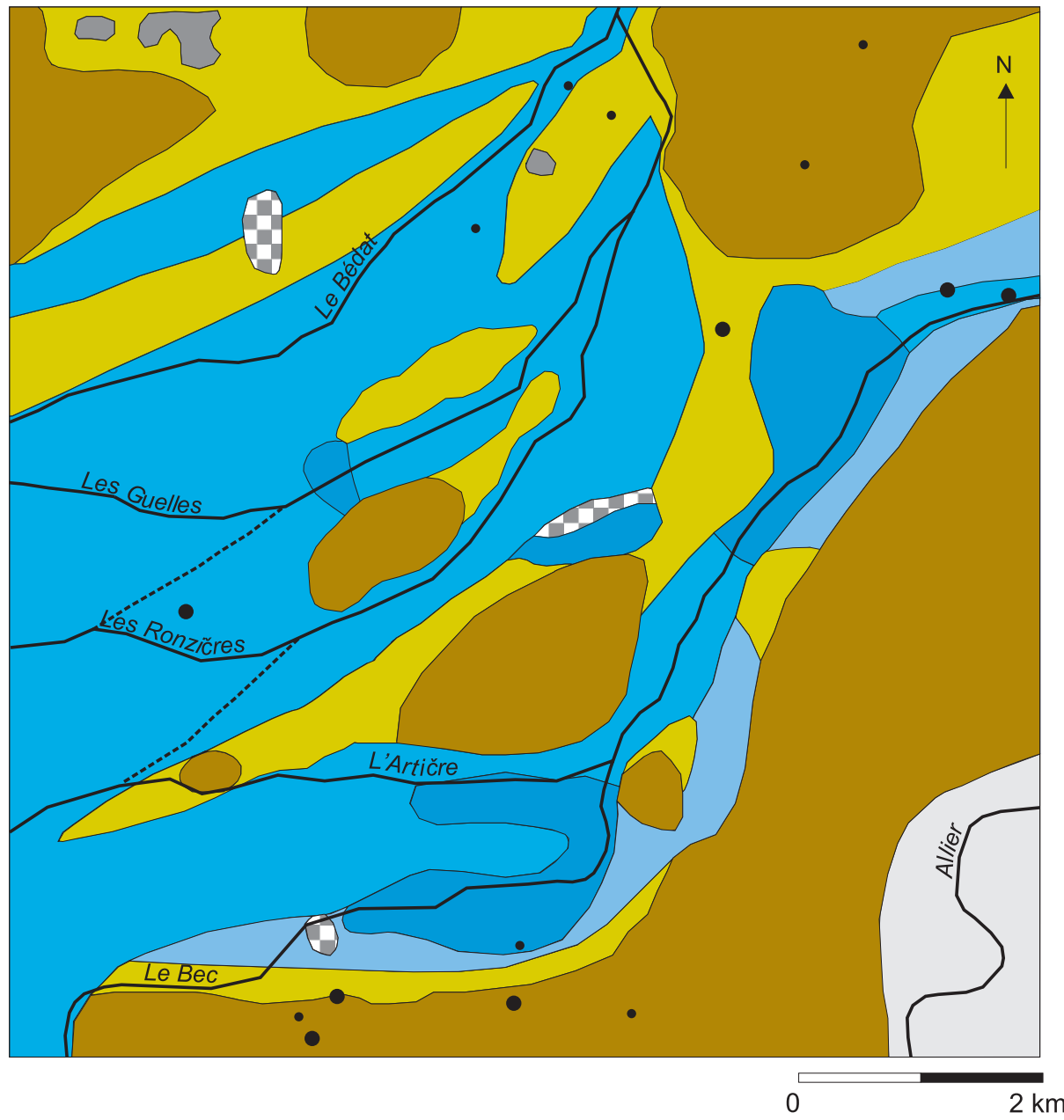

\section{Manifestations of the dampness}

Sub-surface ground water

Slopes of the Limagne, residual hills around the damp area, hills of the marly plain

Sub-surface ground water and low permeability soils Higher parts of the marly plain

Soils deeply saturated in water $(30-50 \mathrm{~cm})$

Depressions now filled in by colluvial deposits from the slopes.

Seasonal rise of ground water

Depressions corresponding to the drainage axes in the marly plain (centre of würmian basins)
Surface ground water

Areas of marked stagnation of water

\section{Area not studied}

Valley of the river Allier

\section{Particular cases}

Salted soils

Anthropogenic filling

Fig. 5 The relationships between societies and damp areas from the final Bronze Age to the beginning of La Tene Sl.5. Odnos između društvenih zajednica i vlažnih područja od kasnog brončanog doba do početka razdoblja La Tene 


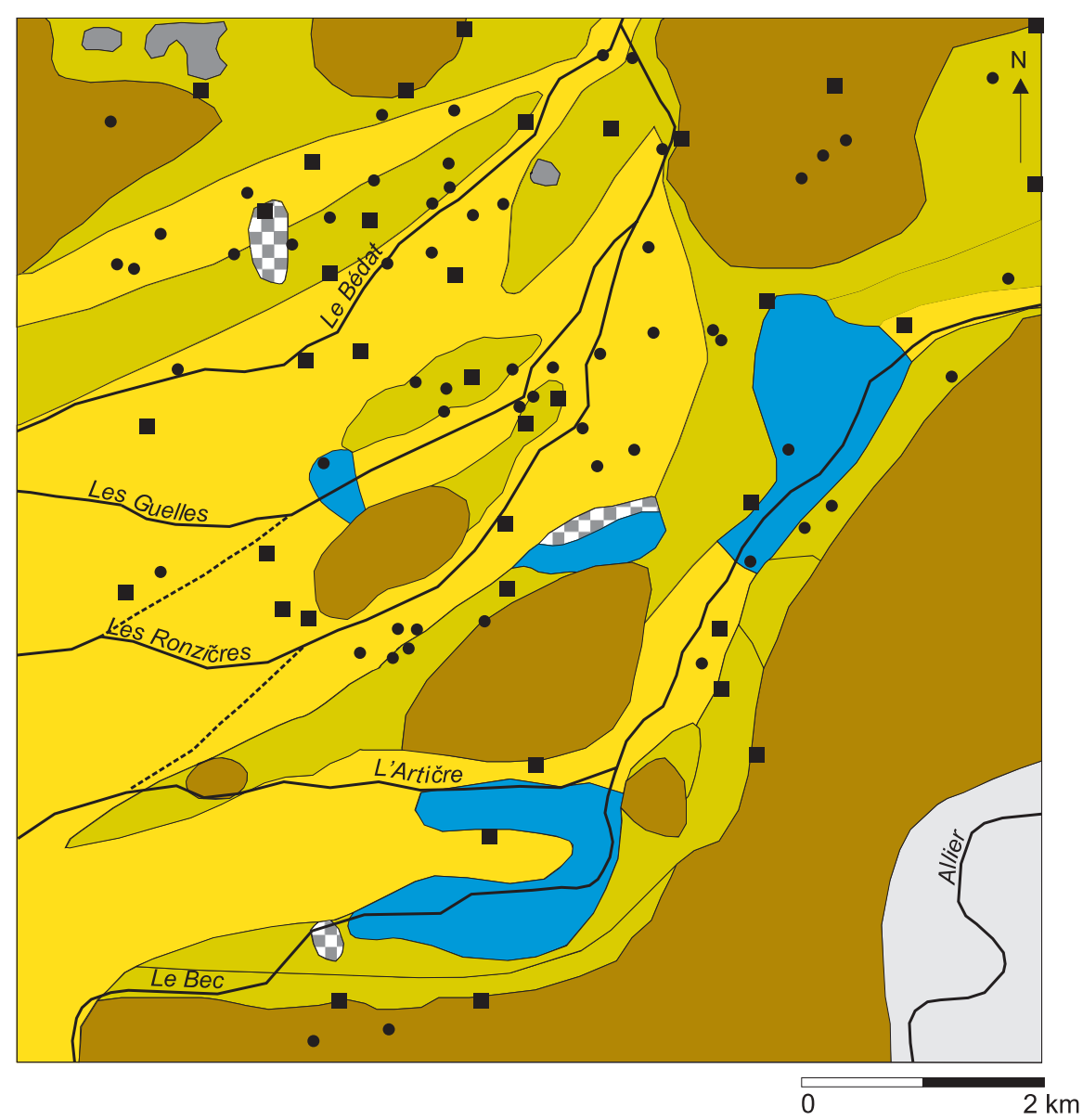

\section{Manifestations of the dampness}

Sub-surface ground water

Slopes of the Limagne, residual hills around the damp area, hills of the marly plain

Surface ground water (seasonal)

Areas of marked stagnation of water

Sub-surface ground water and low permeability soils Higher parts of the marly plain

Subsurface ground water due to drainage systems and low permeability soils

Depressions corresponding to the drainage axes in the marly plain

Seasonal rise of ground water

Depressions corresponding to the drainage axes in the marly plain (centre of würmian basins)

\section{Area not studied}

Valley of the river Allier

\section{Particular cases}

Salted soils

Anthropogenic filling

Fig. 6 The relationships between societies and damp areas from the end of La Tene to the High Empire Sl. 6. Odnos između društvenih zajednica i vlažnih područja od razdoblja La Tene do Kasnog carstva 
Christèle Ballut, Frédéric Trement - Environmental Changes and Evolution of Settlement in the Limagne of Clermont-Ferrand (Massif Central, France)

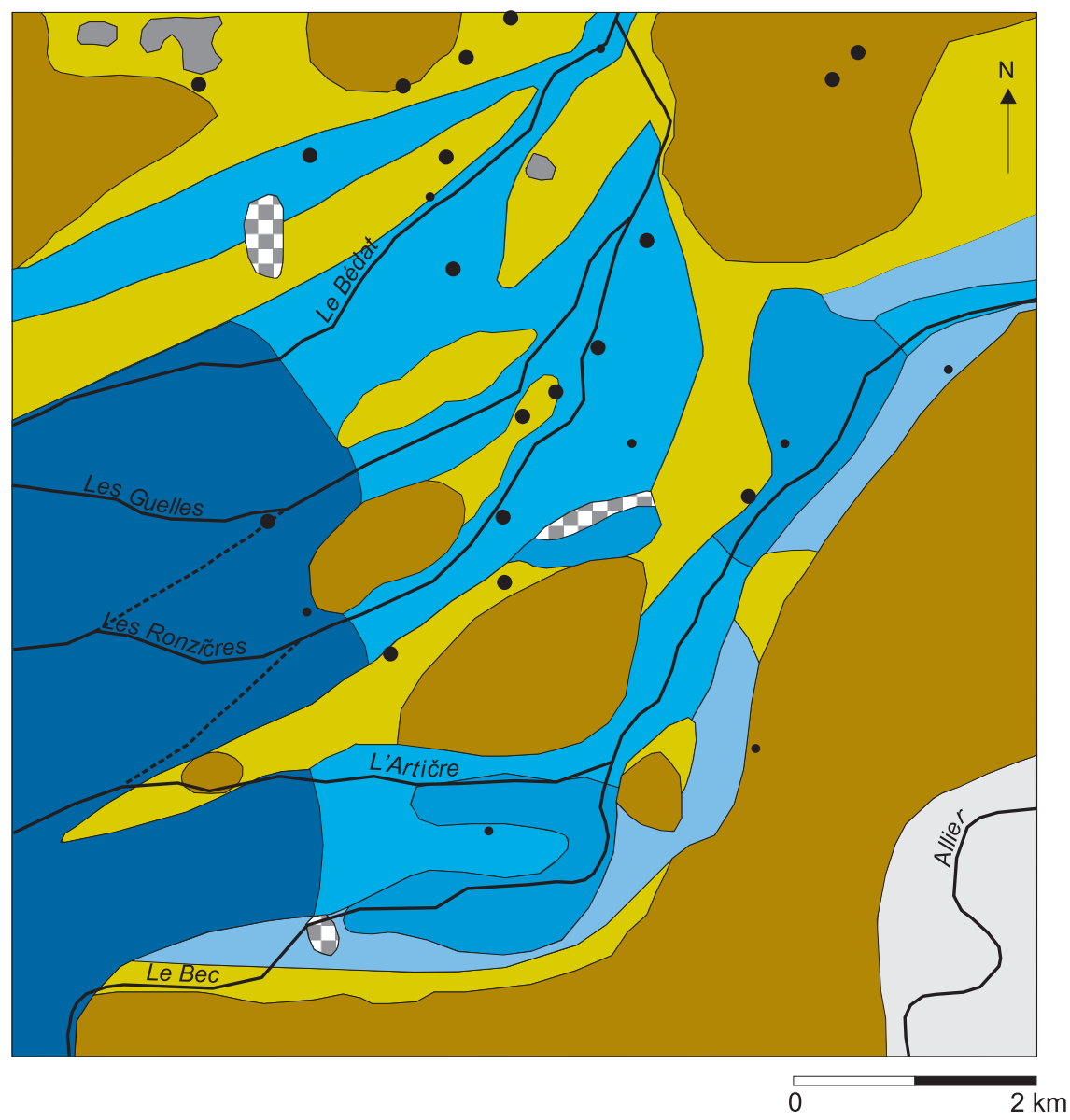

Manifestations of the dampness

Sub-surface ground water

Slopes of the Limagne, residual hills around the damp area, hills of the marly plain

Sub-surface ground water and low permeability soils Higher parts of the marly plain

Soils deeply saturated in water $(30-50 \mathrm{~cm})$

Depressions now filled in by colluvial deposits from the slopes.

Frequent river overflowing causing water stagnation Depressions corresponding to the drainage axes in the marly plain (centre of würmian basins)

Seasonal rise of ground water

Depressions corresponding to the drainage axes in the marly plain (centre of würmian basins)
Surface ground water

Areas of marked stagnation of water

\section{Area not studied}

Valley of the river Allier

\section{Particular cases}

Salted soils

Anthropogenic filling

Fig. 7 The relationships between societies and damp areas from the late Antiquity to the Early Middle Ages Sl. 7. Odnos između društvenih zajednica i vlažnih područja od kasne Antike do ranog srednjeg vijeka 
Slika 5. - legenda

\section{Pokazatelji vlažnosti}

Temeljinica u podzemlju

Padine Limagne, rezidualni brežuljci oko vlažnog

područja, brežuljci laporovite ravnice

Temeljnica u podzemlju i slabo permeabilna tla

Viši dijelovi laporovite ravnice

Tla zasićena vodom $(30-50 \mathrm{~cm})$

Depresije danas zapunjene padinskim

koluvijalnim materijalom

Sezonsko podizanje temeljnice

Udubljenja odgovaraju pravcima drenaže na području laporovite ravnice (centar würmskih bazena)

Slika 6. - legenda

\section{Pokazatelji vlažnosti}

Temelinica u podzemlju

Padine Limagne, rezidualni brežuljci oko vlažnog

područja, brežuljci laporovite ravnice

Temeljnica u podzemlju i slabo permeabilna tla

Viši dijelovi laporovite ravnice

\section{Temeljnica u podzemlju zbog drenažnog sustava i}

slabo permeabilnih tala

Udubljenja odgovaraju pravcima drenaže na području laporovite ravnice Sezonsko podizanje temeljnice

\section{Sezonsko podizanje temeljnice}

Udubljenja odgovaraju pravcima drenaže na području laporovite ravnice (centar würmskih bazena)

Slika 7. - legenda

\section{Pokazatelji vlažnosti}

\section{Temeljnica u podzemlju}

Padine Limagne, rezidualni brežuljci oko vlažnog

područja, brežuljci laporovite ravnice

\section{Temeljica u podzemlju islabo permeabilna tla}

Viši dijelovi laporovite ravnice

\section{Tla zasicena vodom $(30-50 \mathrm{~cm})$}

Depresije danas zapunjene padinskim

koluvijalnim materijalom

\section{Ceste poplave uzrokuju stagnaciju vode}

Udubljenja odgovaraju pravcima drenaže na području laporovite ravnice (centar würmskih bazena)

\section{Sezonsko podizanje temeljinice}

Udubljenja odgovaraju pravcima drenaže na području laporovite ravnice (centar würmskih bazena)

Temeljnica na površini

Zone obilježene stagnacijom vode

Prostor izvan istraživanog područja

Dolina rijeke Allier

\section{Specifični slučajevi}

Slana tla

Antropogeno punjenje

\section{Temeljnica na površini}

Zone obilježene stagnacijom vode

\section{Prostor izvan istraživanog područja}

Dolina rijeke Allier

\section{Specifični slučajevi}

Slana tla

Antropogeno punjenje

Temeljnica na površini

Zone obilježene stagnacijom vode

Prostor izvan istraživanog područja

Dolina rijeke Allier

\section{Specifični slučajevi}

Slana tla

Antropogeno punjenje 
Christèle Ballut, Frédéric Trement - Environmental Changes and Evolution of Settlement in the Limagne of Clermont-Ferrand (Massif Central, France)

\section{CONCLUSION}

This interdisciplinary work realised in the Zone Atelier programme (CNRS) has two main interests. It offers a better understanding of the causes of environmental modifications (influence of climatic, anthropogenic and tectonic factors). Moreover, it provides a spatialisation of environmental data and an approach of the relationships between societies and their environment.

In the Grande Limagne, archaeological and palaeo-environmental research has led to a reconsideration of knowledge and questioning on these relationships, especially during the Iron Age and the Roman period. The present paper offers a preliminary regional synthesis that shows that there is neither physical nor social determinism.

\section{BIBLIOGRAPHY}

Ballut, C., 2000. Evolution environnementale de la Limagne de Clermont-Ferrand au cours de la seconde moitié de l'Holocène (Massif Central français). Thèse de doctorat nouveau régime, sous la direction de Y. Lageat et B. Valadas, Université de Limoges.

Ballut, C., 2001. Evolution géomorphologique et hydrologique dans les marais de Limagne au cours de la seconde moitié de l'Holocène (Massif Central, France). Quaternaire, 12, (1-2), pp. 43-51.

Bornand, M., Callot, G., Favrot, J.-C. et Servat, E., 1968. Les sols du Val d'Allier. Notice explicative de la carte pédologique au 1:100000. INRA, Service d'étude des sols, Montpellier, 199 p.

Bravard, J.-P., Petit, F., 1997. Les cours d'eau. Dynamique du système fluvial. Paris, Armand Colin, 222 p.

Brown, A.-G., 1997. Alluvial geoarchaeology, floodplain archaeology and environmental change. Cambridge University Press, 377 p.

Brown, A.-G., Quine, T.-A., 1999. Fluvial processus and environmental change. Chichester, John Wiley and sons, $413 \mathrm{p}$.

Burnouf, J. (coord.), 1999, Programme Interactions homme/milieu dans le bassin versant de la Loire (fin du Tardiglaciaire-époque indusstrielle), plan d'action conjoint du Département des Sciences de l'Homme et de la Société et du Programme Interdisciplinaire de Recherche environnement, vie et sociétés, comité Environnement, Sociétés et Développement à Long Terme, UMR 6575, archéologie des territoires, Tours, 2 volumes.

Daugas, J.-P. et Tixier, L., 1977. Variations paléoclimatiques de la Limagne d'Auvergne. Approche écologique de l'homme fossile, Paris, 1975, suppl. de l'Association Française pour l'Etude du Quaternaire, 47 : 203-235.

Derruau, M., 1949. La Grande Limagne auvergnate et bourbonnaise. Thèse principale, Grenoble, 545 p.

Fournier, G., 1960. Essai sur le peuplement de la Basse Auvergne à l'époque gallo-romaine. Revue d'Auvergne, $73: 129-163$.

Fournier, G., 1962. Le peuplement en Basse Auvergne durant le haut Moyen-Age. PUF, Paris, 678 p.

Jorda, M. et Provansal, M., 1996. Impact de l'anthropisation et du climat sur le détritisme en France du sud-est (Alpes du sud et Provence). Bulletin de la Société Géologique de France, 167, 1, pp.159-168.

Gachon, L., 1963. Contribution à l'étude du Quaternaire récent de la Grande Limagne marno-calcaire : morphogenèse et pédogenèse. Thèse d'Etat, Clermont-Ferrand, $169 \mathrm{p}$.

Guichard, V., 2000. Autoroute A710. Archéologie préventive. DFS, archives SRA Auvergne. Clermont-Ferrand, 5 vol.

Magny, M., 1995. Une histoire du climat. Des derniers mammouths au siècle de l'automobile. Paris, Erance, 176 p.

Neboit, R., 1983. L'homme et l'érosion. Faculté des Lettres et Sciences humaines, Université de ClermontFerrand II, fasc. 17, nouvelle série. 
Neboit, R., 1999. Autour du concept d'érosion accélérée : l'homme, le temps et la morphogenèse. Géomorphologie : relief, processus, environnement, 2 : 159-172.

Trément F., Ballut C., Mennessier-Jouannet C., Argant J., 2002. Mutations environnementales et systèmes socio-économiques en Grande Limagne (Massif central) de l'Age du Fer au Moyen-Age. Actes du colloque Equilibres et ruptures dans les écosystèmes durant les 20 derniers millénaires : durabilité et mutation. Annales de l'Université de Franche-Comté, Besançon, pp. 269-279.

Trément F., Ballut C., Dousteyssier B., Guichard V., Segard M., 2004. Habitat et milieu humide en Grande Limagne de l'Age du Fer au Moyen-Age. Essai de spatialisation dynamique des relations sociétés-milieux. Actes du colloque PEVS-SEDD du CNRS « Les fleuves aussiont une histoire 2 : Pratiques sociales et hydrosystèmes fluviaux, lacustres et palustres des sociétés pré-industrielles ». Aix-en-Provence (8-10 avril 2002). Paris, CTHS, p. 95-110.

\title{
SAŽETAK
}

\section{Promjene okoliša i evolucija naseljavanja na području ravnice Limagne u blizini Clermont-Ferranda (Centralni francuski masiv)}

\author{
Christèle BALLUT, Frédéric TREMENT
}

Ovaj je rad ostvaren unutar interdisciplinarnog programa zvanog Zone Atelier (CNRS). Cilj mu je analiza odnosa složenih hidroloških obilježja istraživanog područja i razvoja naseljavanja od ranog željeznog doba do ranog srednjeg vijeka u močvari Limagne (Centralni francuski masiv). Ovo istraživanje paleo-okoliša se bazira na usporedbi geomorfoloških i paleohidroloških podataka $\mathrm{s}$ arheološkim podacima o korištenju zemljišta. Ova je geomorfološka studija pokazala promjene vlažnosti u vremenu i prostoru. Homogenost krajolika močvare Limagne je zapravo privid iza kojeg se zapravo krije jedan prostorni mozaik Što više, vlažnost je zapravo bila povezana s klimatskim promjenama, antropogenim utjecajima i vjerojatnom subsidencijom tog prostora. S druge strane, sustavna terenska istraživanja u posljednjih nekoliko godina pokazala su iznimnu gustoću naseljenosti, što je nespojivo s idejom odbojne močvare za prethistorijsko i antičko stanovanje. Prostorni raspored geomorfoloških i arheoloških podataka otkriva vezu između evolucije vlažnih zona, oblika i gustoće naseljavanja, kao i ekonomsko korištenje tih područja.

Ovaj interdisciplinarni rad izdvaja dva glavna interesa. Nudi bolje razumijevanje uzroka promjena okoliša: utjcaja klime, antropogenih i tektonskih faktora. Štoviše, on daje prostorne i environmentalne podatke, a i pojašnjava odnose između društva i njegovog okoliša. U ravnici Grande Limagne arheološka i palo-environmentalistička istraživanja dovela su do ponovnog razmatranja dotad poznatih činjenica i ponovnog postavljanja pitanja o tim međuodnosima, posebno u vrijme Željeznog doba i u Rimskom periodu. Ovaj rad daje preliminarnu regionalnu sintezu koja pokazuje da ne postoji ni fizički ni socijalni determinizam.

Received (Primljeno): 2006 - 08 - 31

Accepted (Prihvaćeno): 2006 - 04 - 30

\section{Christèle Ballut}

Laboratory of Physical Geography, UMR 6042-CNRS, 4 rue Ledru, 63057 Clermont-Ferrand, christeleballut@hotmail.com

Frédéric Trement

Ancient Civilisations Research Center (CRCA), Université Blaise Pascal, 4 rue Ledru, 63057 Clermont-Ferrand, frederic.trement@wanadoo.fr 